\title{
Application of Acrylonitrile Butadiene Rubber for Management of Industrial Waste Silica
}

\author{
M.M.El-Toony* and K.F.EI-Nemr
}

National Center for Radiation Research and Technology, Atomic Energy Authority, Egypt

\begin{abstract}
Some glass factories have drilled and milled silica mixed with water, their treatment depends on precipitation, filtration etc. New concept for recycling of waste have paid attention to taking samples from different steps of traditional treatment, water evaporation of samples have been carried out. Investigation of attained powdered using EDX showed that, about $95.87 \%$ of sample was silica while particle size analyzer proved that it was not exceeding 73 micrometer. Silica powder mixed with Acrylonitrile Butadiene Rubber using miller and moreover thermal compression were performed to achieve maximum compatibility and constant thickness of the composite. Electron beam irradiation of the samples with different doses 25 and $100 \mathrm{KGy}$ were carried out. Mechanical investigation using stress strain technique, showing that pure silica composite was more than waste silica composite of step one by small value. Thermal characterization was studied using thermal gravimetric analysis proved that improvement of the silica waste / NBR composite than that of pure composite and also for electrical properties of the composite which have the same behavior. These results confirmed application of waste silica instead of pure one with NBR composites and management of environmentally problem such as water polluted with waste silica.
\end{abstract}

Keywords: Composite; Silica waste; Recycling; Irradiation; Thermal behavior

\section{Introduction}

Polymer materials have served mankind for decades. They are used in a wide range of industrial applications including packaging, transportation, construction, pharmacy and the food industry world wide. Elastomers are probably the most versatile and useful groups of polymers ever known to man. These materials are used to manufacture articles such as tires, isolation bearings, roofing sheets, seals, electrical cables and hovercraft skirts. Raw elastomers, e.g. natural rubber (NR), have poor properties and must be reinforced. Reinforcement gives improvement in properties such as tear strength, abrasion resistance, stiffness and hardness [1]. This is brought about by the inclusion of solid particles for example carbon black. Fillers and curing agents to a large extent control the technical properties of rubber compounds [28]. Particularly, as a chemical-free biomacromolecule, natural rubber latex (NRL) has been used in manufacturing medical products such as medical gloves, condoms, blood transfusion tubing, catheters, injector closures and safety bags due to its excellent elasticity, flexibility, antivirus permeation, good formability and biodegradability [9-11]. More recently, with the worldwide spread of the epidemic diseases such as Acquired Immure Deficiency Syndrome (AIDS), hepatitis B, Severe Acute Respiratory Syndrome (SARS) and avian influenza A (H5N1), it becomes increasingly important and urgent to develop high performance NRL protective products. Low tensile strength and poor tear resistance are the other major drawbacks encountered in NRL products, especially for medical gloves and condoms. Attempts have been made to use carbon black [12], ultra-fine calcium carbonate [13], modified montmorillonite [14], silica [15] and starch [1] to reinforce dry NR or NRL. However, these traditional reinforcement materials are not so effective for NRL. Therefore, it is essential to exploit new ways to enhance the ageing resistance and mechanical properties for NRL products. Further, such reinforcements are related to the secondary structure of filler particles (agglomerate) [16-18] and the rubber/ filler interactions [19-21]. Silica is also known as an effective filler of rubber reinforcement. Since silica does not have any radical and lone electrons, it does not show any ESR signals. Thus silica filled rubber systems are suitable for the investigation of chain scission of rubber molecules during the deformation. For silica filled rubber systems, the rubber/filler interactions can be controlled by the introduction of coupling agent [22-24].

Tribological studies on $\mathrm{SiO}_{2} /$ acrylate nanocomposites show that friction leads to the gradual loss of $\mathrm{SiO}_{2}$ nanoparticles [25]. In the case that $\mathrm{SiO}_{2}$ nanoparticles are applied in tires, one may expect them to be released by wear. It has been shown that many of the particles released by the interaction between tires and road pavement are $<100 \mathrm{~nm}[26,27]$. Furthermore, nanoparticles may be released when nanocomposites are subjected to wear, such as sanding in the case of coatings and abrasive use in the case of dental fillings [28-30]. Thus, it would seem proper to consider the impact of nanoparticlate $\mathrm{TiO}_{2}$ and amorphous silica after release. There is evidence that amorphous $\mathrm{SiO}_{2}$ nanoparticles may be hazardous to humans [31-33] and may exhibit ecotoxicity [34]. A main molecular mechanism of cytotoxicity in case of both amorphous $\mathrm{SiO}_{2}$ and $\mathrm{TiO}_{2}$ nanoparticles in the absence of light appears to be oxidative damage linked to reactive oxygen species, whereas $\mathrm{TiO}_{2}$ particles exposed to light and/or UV radiation may also damage cells due to photo catalytically enhanced oxidation [35-44]. Changes of the nanoparticulate surface, which may be introduced to achieve a better performance of nanocomposites e.g. [45-48], may in turn affect hazard. All in all, amorphous $\mathrm{SiO}_{2}$ and $\mathrm{TiO}_{2}$ nanoparticles can be hazardous, with actual hazard to a considerable extent dependent on surface characteristics and in case of $\mathrm{TiO}_{2}$ also on crystal structure. Claims that nanocomposites are 'environmentally safe'

*Corresponding author: M.M.El Toony, Egypt, 3 Ahmad El-Zomr street, P.O. Box 29- Nasr City, Cairo, 11370 Tel: 20166721956; Fax:+202 22944 803; E-mail: Toonyoptrade@yahoo.com

Received November 03, 2011; Accepted January 19, 2012; Published January 26, 2012

Citation: El-Toony MM, El-Nemr KF (2012) Application of Acrylonitrile Butadiene Rubber for Management of Industrial Waste Silica. J Material Sci Eng 1:104. doi:10.4172/2169-0022.1000104

Copyright: (C) 2012 El-Toony MM, et al. This is an open-access article distributed under the terms of the Creative Commons Attribution License, which permits unrestricted use, distribution, and reproduction in any medium, provided the original author and source are credited. 
[49-50], 'environment(ally)-friendly' or 'eco-friendly' and that $\mathrm{TiO}_{2}$ nanoparticles are 'non-toxic' do not seem to have a firm foundation in empirical data. Moreover, traditional methods of particulate control such as wastewater treatment plants and filters are often not well suited to efficiently catching $\mathrm{TiO}_{2}$ and $\mathrm{SiO}_{2}$ nanoparticles. There is only very limited research into the performance of recycled nanocomposites which contain organic polymers. One study has considered recycling of layered silicate-thermoplastic olefin elastomeric nanocomposites, focusing on mechanical performance [51]. In this study it was found that though degradation of the nanocomposite during recycling occurred, mechanical properties remained significantly better than those of the neat polymer. More in general one might expect that the oxidative properties of titania and silica nanoparticles are conducive to polymer degradation and will increase thermal degradation over the level occurring in neat polymer when recycling involves heating $[45,52,53]$.

Our results aims to manage the silica waste resulting from manufacturing of glass crystals. The silica waste has different particles size which used as filler with synthetic rubber to improve their mechanical characteristics. Irradiation with electron beam has applied to achieve compatibility and finally cross-linking. Thermal behavior of waste silica / NBR composites have been studied and compared with that of pure silica to show its availability to replace with them.

\section{Experimental Approach}

\section{Materials and methods}

Materials: A commercial grade acrylonitrile-butadiene rubber (Europrene N3345) with $34 \%$ acrylonitrite content was used as the matrix polymer it was purchased from Enichem Company INC., Italy. The recipe of this study contained also other additives, namely: $\mathrm{ZnO}$, stearic acid (from El-nasr Phosphate Company (Egypt). Pentaerthenol triacrylate (PETriA) from Aldrish (Germany) used as sensitizer. The first two additives act as accelerators as well as activators and their content was $5 \mathrm{phr}$ and $1 \mathrm{phr}$, respectively.

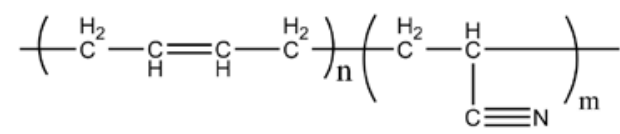

\section{Diagram showing the formula of NBR}

Sample Preparation: NBR, $\mathrm{ZnO}$, stearic acid and silica followed by sensitizer were mixed on a rubber mill $(300 \times 470 \mathrm{~mm})$. The blends composite sheets were then compression molded into sheets of 4 $\mathrm{mm}$ thickness at $160^{\circ} \mathrm{C}$ under a pressure of for $10 \mathrm{~min}$. Irradiation by Electron beam accelerator was carried out for achieve optimum com.

\section{Powdered characterization}

EDX Measurements: Oxford-tests attached to Scan Electron Microscope (SEM), Joel- 5400, Japan.

\section{Calibration data:- Gain factor: 49.996, Live time: 80 Seconds.}

Sample data:- Total spectrum count: 875722 , Live time: 70 Seconds, System resolution: $173 \mathrm{eV}$, Accelerating voltage: $20.00 \mathrm{KV}$.

Particle size analyzers: The particle size analysis for different types of silica was carried out by using Quantachrome porosimeter (Pore Master 60) from Florida, (USA) depending on automatic mercury intrusion under high pressure 60, 000 psia.

\section{Mechanical properties measurements}

Hardness measurements: Samples of at least $1 \mathrm{~mm}$ in thickness with flat surface were cut for hardness test. The measurement was carried out according to (ASTM D2240, 2000) used to examine by analogue manual instrument of hardness tester with thin pin it is termed Baxio USA. The unit of hardness is expressed in (Shore A).

Tensile measurements: Five individual dumbbell-shaped specimens were cut out from the sheets using a steel die of standard width $(4 \mathrm{~mm})$. The minimum thickness of the test specimens was determined by gauge graduated to one hundredth of the $\mathrm{mm}$. A bench mark of $1.5 \mathrm{~cm}$ was made on working part of each test specimen. The ultimate tensile strength and elongation at break point were determined at crosshead speed $500 \mathrm{~mm} / \mathrm{min}$ on a rubber tensile testing machine Instron Machine model 1195, (England). The measurement was carried out according to (ASTM D-412-66T), in which the standard deviation was $\pm 5 \%$.

\section{Electrical properties}

AC impedance spectroscopy measurements over a frequency of $10^{6}$ $\mathrm{Hz}$ using a system 3532 Hioiki bridge LCR hi tester. Each composite sample was cut into sections $2.5 \mathrm{~cm} \times 2.0 \mathrm{~cm}$ prior to being mounted in the cell.

\section{Thermal Properties measurements}

Thermal Gravimetric Analysis: Shimadzu TGA -50, Japan, was used to characterize the thermal stability of the different composites. Thermal analysis was carried out using a thermal gravimetric analysis (TGA) apparatus, samples of $0.98-1.5 \mathrm{mg}$ were encapsulated in aluminum pans and heated from 50 up to $500^{\circ} \mathrm{C}$ at heating rate $10^{\circ} \mathrm{C}$ $/ \mathrm{min}$.

\section{Results and Discussion}

\section{Silica powdered characterization}

Chemical characterization of waste silica and pure by EDX (Table 1): It is apparent that waste silica of step one contain $95.87 \%$ silica which is less than pure silica by $2.19 \%$. it has traces of aluminum, sulfur, titanium, copper, zinc and tin while the latter 4 elements have disappeared completely in pure silica. Silica of step two differ from that of step one by raising of aluminum concentration to about $16 \%$ which is due to adding of alum to clarify the silica- water suspension as this drilled silica is desired to get ride off. Metal traces of step two silica such as titanium has about double value of step one while copper and zinc are triple time of step one. Tin have disappeared completely in silica of step two while sulfur has the same value in step one and step two. Silica of step two has $79.09 \%$ value of its weight so it decreased by $18.97 \%$ from the pure silica.

Particle size analyses of the silica (waste and pure one) (Table 2): As it seen from table 2 waste silica of waste silica of step one and two is larger than pure silica while silica of step two $(73 \mu \mathrm{m})$ is larger than that of step one $(66 \mu \mathrm{m})$. It may due to adding alum have important role for precipitation of more silica particles have larger and smaller particle size. Particle size of step two has larger particle size which may due to different traces of metals by higher ratio than that of step one waste silica. The included trace metals included higher atomic radius than pure silica besides their ability to form a complexes such as aluminum. Aluminum has a capability to react with acids and alkali which raise their probability to form higher particle sized compounds. Surface area of waste silica particles are varied with a large range compared to pure silica. 


\begin{tabular}{|c|c|c|c|c|c|c|c|}
\hline No. & 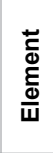 & $\begin{array}{l}\text { Element } \\
\% \text { of } \\
\text { Pure } \\
\text { silica }\end{array}$ & $\begin{array}{l}\text { Element } \\
\% \text { of } \\
\text { waste } \\
\text { silica } \\
\text { step } 1\end{array}$ & $\begin{array}{l}\text { Element } \\
\% \text { of } \\
\text { waste } \\
\text { silica } \\
\text { step } 2\end{array}$ & $\begin{array}{l}\text { Atomic \% } \\
\text { Pure } \\
\text { silica }\end{array}$ & $\begin{array}{l}\text { Atomic \% } \\
\text { waste } \\
\text { silica } \\
\text { step 1 }\end{array}$ & $\begin{array}{l}\text { Atomic \% } \\
\text { waste } \\
\text { silica } \\
\text { step } 2\end{array}$ \\
\hline 1- & 0 & 15.43 & 8.79 & 11.26 & 37.15 & 27.05 & 26.09 \\
\hline $2-$ & $\mathrm{Al}$ & 0.8 & 0.96 & 11.63 & 1.34 & 1.75 & 15.98 \\
\hline 3- & $\mathrm{Si}$ & 44.4 & 39.26 & 40.16 & 60.89 & 68.82 & 53.00 \\
\hline 4- & $S$ & 0.51 & 0.16 & 0.17 & 0.62 & 0.24 & 0.2 \\
\hline 5- & $\mathrm{Ti}$ & |------ & 0.68 & 2.36 & ------- & 0.7 & 1.83 \\
\hline 6- & $\mathrm{Cu}$ & |------- & 0.69 & 2.73 & |------- & 0.54 & 1.6 \\
\hline 7- & $\mathrm{Zn}$ & ------- & 0.74 & 2.83 & -------- & 0.56 & 1.35 \\
\hline 8- & Sn & -------- & 0.85 & 0.0 & ------- & 0.35 & 0.0 \\
\hline
\end{tabular}

Table 1: Constituents of pure silica and waste silica taken from 2 steps of waste treatment.

\begin{tabular}{|l|l|l|l|}
\hline No. & Pure silica & waste silica step 1 & waste silica step 2 \\
\hline Particle size & $52 \mu \mathrm{m}$ & $66 \mu \mathrm{m}$ & $73 \mu \mathrm{m}$ \\
\hline
\end{tabular}

Table 2: Particle size of pure and waste silica.

\section{Rubber composite characterization}

Nitrile butadiene rubber (NBR) is a family of unsaturated copolymers of 2 propenenitrile and various butadiene monomers (1,2-butadiene and 1,3 butadiene). Although its physical and chemical properties vary depending on the polymer's composition of nitrile (the more nitrile within the polymer, the higher the resistance to oils but the lower the flexibility of the material), this form of synthetic rubber is generally resistant to oil, fuel, and other chemicals. Its resilience makes NBR a useful material for disposable lab, cleaning, and examination gloves. It is used in the automotive industry to make fuel and oil handling hoses, seals, and grommets. NBR's ability to withstand a range of temperatures from $-40^{\circ} \mathrm{C}$ to $+108^{\circ} \mathrm{C}$ makes it an ideal material for extreme automotive applications. Nitrile butadiene is also used to create moulded goods, footwear, adhesives, sealants, sponge, expanded foams, and floor mats. Nitrile rubber is more resistant than natural rubber to oils and acids, but has inferior strength and flexibility. Nitrile gloves are nonetheless three times more puncture-resistant than rubber gloves [54]. Nitrile rubber is generally resistant to aliphatic hydrocarbons. Nitrile, like natural rubber, can be attacked by ozone, aromatic hydrocarbons, ketones, esters and aldehydes.

When nano or micro particles are dispersed with polymers, a core shell structure tends to be formed in which nanoparticles covered with polymeric chains under certain conditions such as those used for selfassembly. By employing this approach, Caruso et al. [55] developed core-shell materials with given size, topology, and composition. Han and Armes [56] and Rotstein and Tannenbaum [57] studied polypyrrole, polystyrene and silica nanocomposites, respectively, and also confirmed the formation of this core-shell structure. In the present study, $\mathrm{SiO}_{2}$ nanoparticles act as cores or templates to adsorb NBR particles to develop a bulk $\mathrm{NBR} / \mathrm{SiO}_{2}$ microcomposite. There is electrostatic adsorption stage in this process figure 1 [58]. Electron beam irradiation play very important role in cross linking of NBR and silica; irradiate the composite make a homolitic and heterolytic fission upon NBR rubber which firstly surrounded the silica mechanically and thermally. Positive charged arising by irradiation on NBR adsorbed on negatively charged silica powdered. Positively charged trace metals which have investigated by EDX may play an important role for tightly compatiblization to NBR especially waste silica taken from step two (Figure 1).

\section{Mechanical properties of rubber composites}

Hardness properties: Hardness and 300\% modulus of all vulcanizates are illustrated in table 3 . As expected, the gum gives the lowest hardness and modulus while hardness and modulus increase noticeably when pure silica is added to the NBR. At $40 \%$ amounts of filler, step one vulcanizate exhibits nearly equal stiffness with waste silica step two silica-filled composite. In addition, the results showed that small difference of hardness between step one waste silica composites when it compared with composite of pure one. Hardness of composite increased upon $100 \mathrm{KGy}$ irradiation using Electron beam irradiation as it seen in table 3. This is thought to be due to the decrease in crosslink density when high silica loading is used at $25 \mathrm{KGy}$. In a previous study, crosslink density of NR vulcanizates gradually decreases when silica loading is more than $20 \mathrm{phr}$ [59]. The explanation is given as the adsorption of zinc complex on the silica surface, thus lowering the sulfur vulcanization efficiency. (Table 3 )

Stress strain of rubber composite (Figure 2) (Table 4): It is well known that the stress-strain curves for silica filled rubber systems are affected by the crosslink density of rubber matrix [60,61], the size of agglomerates formed by the silica $[62,63]$ and rubber / silica interactions $[64,60]$. These effects can be controlled by the contents of curing agents, the number of silanol groups on silica particles and the introduction of coupling agent. Irradiation by electron beam have advantageous role for cross linking and so on composite stress strain. Waste silica composites have improved mechanical character than that of pure one which represented by two samples first of which (sample 1) irradiated by $25 \mathrm{KGy}$. While second one which irradiated by 100 KGy was termed sample 4 . The irradiated samples with $100 \mathrm{KGy}$ dose have higher stress value while that irradiated with $25 \mathrm{KGy}$ have higher strain value it may due to incomplete cross linking between inorganic particles and the rubber understudy. These results may be explained by higher cross-linking have attained by higher irradiation dose in the range of $100 \mathrm{KGy}$.

Electrical behaviors of rubber composite: The dielectric behavior of composite materials can be also changed depending on the particle size of the added particles. Some degree of dielectric enhancement

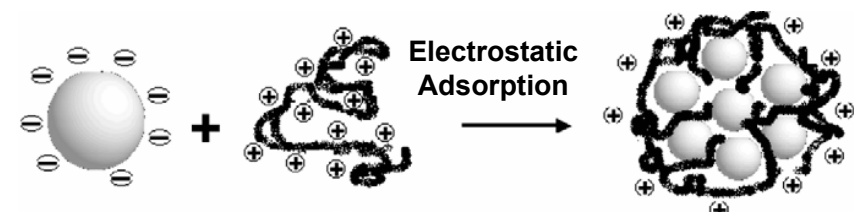

Silica NBR after irradiation cross linking composite

Figure 1:

\begin{tabular}{|c|c|c|}
\hline No. & Sample & $\begin{array}{l}\text { Hardness } \\
\text { (Shore-A) }\end{array}$ \\
\hline $1-$ & NBR with no additive and irradiation at 25KGy (Blank) & 38 \\
\hline $2-$ & NBR with no additive and irradiation at $100 \mathrm{KGy}$ (Blank) & 41 \\
\hline 3- & NBR with pure silica additive and irradiation at $25 \mathrm{KGy}$ & 54 \\
\hline 4- & NBR with waste silica step 1 additive and irradiation at $25 \mathrm{KGy}$ & 51 \\
\hline $5-$ & NBR with waste silica step 2 additive and irradiation at $25 \mathrm{KGy}$ & 54 \\
\hline 6- & NBR with pure silica additive and irradiation at $100 \mathrm{KGy}$ & 62 \\
\hline 7- & $\begin{array}{l}\text { NBR with waste silica step } 1 \text { additive and irradiation at } 100 \\
\text { KGy }\end{array}$ & 59 \\
\hline 8- & $\begin{array}{l}\text { NBR with waste silica step } 2 \text { additive and irradiation at } 100 \\
\text { KGy }\end{array}$ & 64 \\
\hline
\end{tabular}

Table 3: Study of hardness of pure and waste silica /NBR composite. 


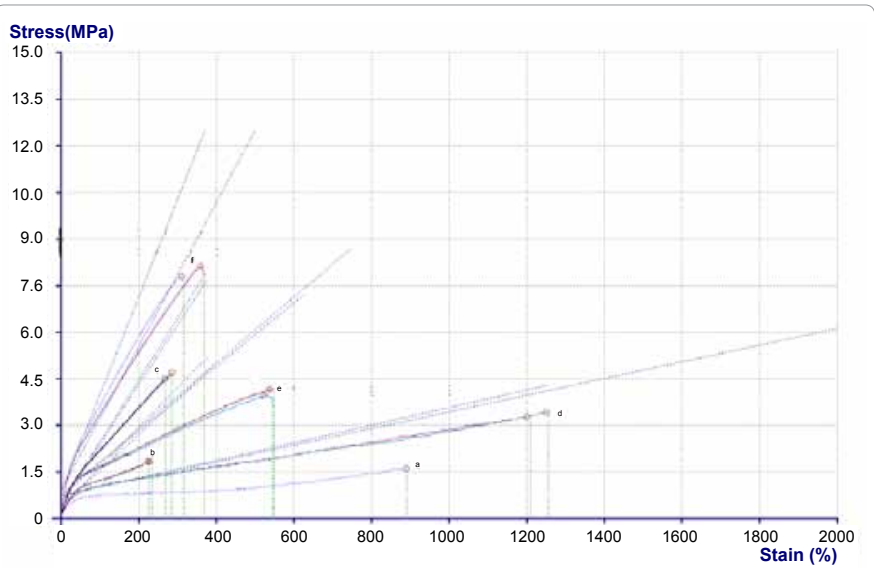

a) Pure silica at $25 \mathrm{KGy}$ irradiation

b) Waste silica discharged from step one at $25 \mathrm{KGy}$ irradiation

c) Waste silica discharged from step two at $25 \mathrm{KGy}$ irradiation

d) Pure silica at 100 KGy irradiation

e) Waste silica discharged from step one at $100 \mathrm{KGy}$ irradiation

f) Waste silica discharged from step two at $100 \mathrm{KGy}$ irradiation

Figure 2: Stress strain curve NBR/ silica composites.

was reported for composite materials with dispersed $\mathrm{Al}_{2} \mathrm{O}_{3}, \mathrm{SiO}_{2}$, $\mathrm{TiO}_{2}$ particles as the particle size decreases from a typical bulk value to a nanometer scale $[65,66]$. The dielectric differences between nanometer-sized and bulk-sized particles can be seen in the ColeCole plot. The dielectric enhancement is attributed to the dipoles associated with the interfaces of the nanometer-sized particles, which are created because of the presence of dangling bonds, twisted bonds or bonds with adsorbed foreign molecules. In the case of heterogeneous systems, where materials of different electrical properties contact each other, the charges at the interfaces can additionally build-up [67]. For the investigated systems such dipoles can result from the rubber-filler ionic interactions when silica was used. Therefore we assume that the concentration of dipoles present in the system varies with the amount of added silica, that is reflected by the relaxation strength, $\Delta \varepsilon=\varepsilon 0-$ $\varepsilon \infty$ calculated from Cole-Cole plots for $\alpha$ - relaxation. The highest value of the relaxation strength was obtained for the vulcanizates filled with silica synthesized from $40 \%$ of silica, as one would expect as shown in table 4. Therefore, this behavior could result from the highest amount of silica, charges on its surface and its interactions with rubber chains. The Cole-Cole plot for the investigated systems demonstrates a major deviation from semicircle, especially at low frequencies, which indicates not only a large distribution of relaxation times, but can be also due to the presence of nanometer size particles. The differences in the positions of Cole-Cole for the investigated systems could be the result of the volume fraction of particles as well as the distribution of the particles morphology, shape or structural interactions. Irradiation dose has an important role for composite compatiblization $100 \mathrm{KGy}$ is advantageous dose over $25 \mathrm{KGy}$ and so electrical conductivity is less in larger dose. Pure silica/NBR composite is less in EC comparing to that of waste silica composite. Waste silica of step two is higher in EC than waste silica step one composite which may due to more concentration of trace metals in this composite as it seen in table 4. (Table 5).

\section{Thermal behaviors}

Thermal gravimetric analysis (Figure 3): The thermal and thermo oxidative ageing resistance of $\mathrm{NBR} / \mathrm{SiO}_{2}$ composite can be assessed, respectively, from the investigation of thermal and thermo oxidative decomposition. There is only one obvious thermal decomposition step of NBR molecular chains, primarily initiated by thermal scissions of $\mathrm{C}-\mathrm{C}$ chain bonds accompanying a transfer of hydrogen at the site of scission.

$40 \%$ pure silica - Nitrile butadiene rubber composite have differentiated into 5 divisions as seen in figure 3. Each division could be expressed on loss of some fragments of the composite (as $\mathrm{CO}, \mathrm{CO}_{2}, \mathrm{CH}_{4}$, $\mathrm{H}_{2} \mathrm{O}$...etc). First division showed loss of $1.85 \%$ of the original weight by raising the temperature to $269^{\circ} \mathrm{C}$ expressed on working temperature which may be explained by loss of water content included through the composite. Second division illustrated gradual low decrease of weight which was $3.5 \%$ from the original value due to heating into $382^{\circ} \mathrm{C}$. The third division described convex curve, loss of weight through which was $17 \%$ by increasing the temperature to $438^{\circ} \mathrm{C}$. $48 \%$ weight loss was observed via the fourth divisions which have occurred by raising the temperature into $477^{\circ} \mathrm{C}$ which may due to loss of the majority of the organic fragments. The fifth division illustrated the tail of the thermo gram which ended at $484^{\circ} \mathrm{C}$ and the weight loss reached to $65 \%$ of the original weight.

Figure $3 \mathrm{~b}$ and illustrated thermo gram of waste silica of $40 \%$ ratio with NBR forming a composite. The thermo gram attained could be characterized into 4 divisions. First division showed $1.85 \%$ loss of weight by raising the temperature into $357^{\circ} \mathrm{C}$ and $373^{\circ} \mathrm{C}$ for the first and second steps of silica/ treatment respectively. This loss of weight described working temperature of the composite that proved their availability with wider range of temperature than pure silica-NBR

\begin{tabular}{|c|c|c|c|c|c|c|}
\hline $\begin{array}{l}\text { Specimen } \\
\text { No. }\end{array}$ & $\begin{array}{c}\text { Specimen } \\
\text { Description }\end{array}$ & E-Mod MPa & Yield MPa & Yield \% & $\begin{array}{l}\text { Break } \\
\mathrm{MPa}\end{array}$ & Break \% \\
\hline 1 & \multirow{2}{*}{$\begin{array}{l}\text { Pure silica } \\
\text { at } 25 \mathrm{KGy}\end{array}$} & 1.145 & 1.847 & 228.8 & 1.847 & 234.4 \\
\hline 1 & & 1.28 & 1.847 & 225 & 1.847 & 226.1 \\
\hline 2 & $\begin{array}{c}\text { Step one } \\
\text { silica at } 25 \\
\text { KGy }\end{array}$ & ------ & 0.1912 & ------- & 1.618 & 890 \\
\hline 3 & \multirow{2}{*}{$\begin{array}{c}\text { Step two } \\
\text { silica at } 25 \\
\text { KGy }\end{array}$} & 0.2845 & 3.289 & 1200 & 3.289 & 1210 \\
\hline 3 & & 0.2694 & 3.421 & 1250 & 3.421 & 1256 \\
\hline 4 & \multirow{2}{*}{$\begin{array}{l}\text { Pure silica } \\
\text { at } 100 \mathrm{KGy}\end{array}$} & 1.917 & 4.705 & 286.1 & 4.705 & 286.1 \\
\hline 4 & & 1.990 & 4.487 & 267 & 4.487 & 269.6 \\
\hline 5 & \multirow{2}{*}{$\begin{array}{c}\text { Step one } \\
\text { silica at } 100 \\
\text { KGy }\end{array}$} & 1.033 & 3.977 & 523 & 3.784 & 546 \\
\hline 5 & & 1.062 & 4.170 & 537 & 4.125 & 548 \\
\hline 6 & \multirow{2}{*}{$\begin{array}{c}\text { Step two } \\
\text { silica at } 100 \\
\text { KGy }\end{array}$} & 3.137 & 7.79 & 310.5 & 7.59 & 315 \\
\hline 6 & & 2.628 & 8.12 & 359.0 & 7.84 & 368 \\
\hline
\end{tabular}

Table 4: Study of tensile of pure and waste silica /NBR composite.

\begin{tabular}{|c|l|c|}
\hline No. & \multicolumn{1}{|c|}{ Sample } & $\begin{array}{l}\text { Electrical conductivity } \\
\boldsymbol{\mu} \text { Simon / Cm }\end{array}$ \\
\hline $1-$ & NBR with no additive and irradiation at 25KGy & $4 \times 10^{-12}$ \\
\hline $2-$ & NBR with no additive and irradiation at 100KGy & $6 \times 10^{-12}$ \\
\hline $3-$ & $\begin{array}{l}\text { NBR with pure silica additive and irradiation at } \\
25 K G y\end{array}$ & $8 \times 10^{-11}$ \\
\hline $4-$ & $\begin{array}{l}\text { NBR with pure silica additive and irradiation at } \\
\text { 100 KGy }\end{array}$ & $5 \times 10^{-11}$ \\
\hline $5-$ & $\begin{array}{l}\text { NBR with waste silica step 1 additive and } \\
\text { irradiation at 25 KGy }\end{array}$ & $3 \times 10^{-9}$ \\
\hline $6-$ & $\begin{array}{l}\text { NBR with waste silica step 1 additive and } \\
\text { irradiation at 100 KGy }\end{array}$ & $9 \times 10^{-10}$ \\
\hline $7-$ & $\begin{array}{l}\text { NBR with waste silica step 2 additive and } \\
\text { irradiation at 25 KGy }\end{array}$ & $6 \times 10^{-9}$ \\
\hline $8-$ & $\begin{array}{l}\text { NBR with waste silica step 2 additive and } \\
\text { irradiation at 100 KGy }\end{array}$ & $2 \times 10^{-9}$ \\
\hline
\end{tabular}

Table 5: Study of Electrical conductivity of pure and waste silica /NBR composite. 


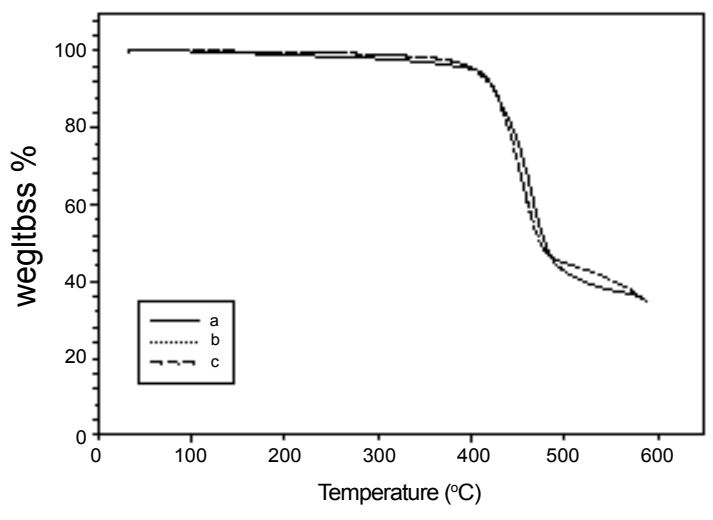

a) Pure silica

b) Waste silica discharged from step one

c) Waste silica discharged from step two

Figure 3: Thermo-gravimetric analysis of NBR/ silica composites.

composite. While second step waste silica-NBR composite has more thermal stability than step one waste silica-NBR composite. The second division showed 16.5 and $16 \%$ loss of weight by heating the composite to $433^{\circ} \mathrm{C}$ and $435^{\circ} \mathrm{C}$ for step one silica silica composite and second one in regular manner. There were dramatic weight decrease ended at $47.5 \%$ for the first step waste silica-NBR composite and 52\% weight decreased was attained by the second step waste silica-rubber composite. This division (Third division) attempt more thermal stability of the first step waste silica / NBR composite than that of step one's silica composite. The fourth division described weight loss which ended at $65 \%$ weight loss from the original value for the two thermograms by heating the temperature into $586^{\circ} \mathrm{C}$. The two thermograms attempt more compatibility of waste silica than pure one through the composite with NBR.

\section{Conclusion}

This work aims to examine the availability to replace pure silica used for NBR reinforcement by waste silica discharged from glass and crystal factories. This study managed two problems, first of which to overcome a serious environmentally one. The second problems depend on cost benefit point of view, through which it could be using no cost waste silica instead of somewhat expensive pure one. This study included evaporation silica suspension to attain silica powdered which have particle size in the range of 50 to 75 micrometer. Mixing the attained silica powdered from two points of waste silica discharges with nitrile butadiene rubber in the ratio of $40 \%$. Electron beam irradiation with different doses ( 25 and $100 \mathrm{KGy}$ ) was exposed on the composites for achieve optimum compatibility and finally crosslinking. $100 \mathrm{KGy}$ irradiation dose have better results than $25 \mathrm{KGy}$. Mechanical properties showed more or less change of tensile strength and hardness by comparing pure silica composites by waste silica one. Thermal and electrical characterizations of the waste silica composite were improved. The attained results confirmed using the waste silica instead of pure one for reinforces NBR to carry out composites having different applications.

\section{References}

1. Dunnom DD (1968) Use of reinforcing silicas. Rubber Age 100: 49-57.

2. Nasir M, Teh GK (1988) The effects of various types of crosslinks on the physical properties of natural rubber. Eur Polym J 24: 733-736.

3. Bristow GM, Tiller RF (1970) Correlation of structure and properties of natural rubber vulcanisates. Kautschuk Und Gummi Kunststoffe 23: 55-59.
4. Dannenberg EM (1975) The effects of surface chemical interactions on the properties of filler-reinforced rubbers. Rubber Chem Technol 48: 410-443.

5. Gregory MJ (1979) Selection of carbon black fillers for natural rubber springs Rubber Chem Technol 52: 996-1007.

6. Pal PK, De SK (1982) Effect of reinforcing silica on vulcanisation, network structure, and technical properties of natural rubber. Rubber Chem Technol 55:1370-88.

7. Okel TA, Waddell WH (1994) Silica properties/rubber performance correlation Carbon black-filled rubber compounds. Rubber Chem Technol 67: 217-236.

8. Ansarifar A, Azhar A, Song M (2003) A new design concept for natural rubber compounds using silanised precipitated silica. J Rubber Res 6: 129-152.

9. Bode HB, Kerkhoff K, Jendrossek D (2001) Bacterial degradation of natural and synthetic rubber. Biomacromolecules 2: 295-303.

10. Schwerin M, Walsh D, Richardson D, Kisielewski R, Kotz R, et al. (2002) Biaxial flex-fatigue and viral penetration of natural rubber latex gloves before and after artificial aging. J Biomed Mater Res 63: 739-745.

11. Walsh DL, Schwerin MR, Kisielewski RW, Kotz RM, Chaput MP, et al. (2004) Abrasion resistance of medical glove materials. J Biomed Mater Res B 68 81-87.

12. Angellier H, Molina-Boisseau S, Dufresne A (2005) Mechanical properties of waxy maize starch nanocrystal reinforced natural rubber. Macromolecules 38 9161-9170.

13. Busfield JJC, Deeprasertkul C, Thomas AG (2000) The effect of liquids on the dynamic properties of carbon black filled natural rubber as a function of prestrain. Polymer 41: 9219-9225.

14. Cai HH, Li SD, Rian TG, Wang HB, Wang JH (2003) Reinforcement of natural rubber latex film by ultrafine calcium carbonate. J Appl Polym Sci 87: 982-985.

15. Arroyo M, Lopez-Manchado MA, Herrero B (2003) Organo-montmorillonite as substitute of carbon black in natural rubber compounds. Polymer 44: 24472453.

16. Jose L, Joseph R (1993) Study of the effect of polyethylene-glycol in field natural-rubber latex vulcanizates. Kaut Gummi Kunstst 46: 220-222.

17. Payne AR, Whittaker RE (1971) Low Strain Dynamic Properties of Filled Rubbers. Rubber Chem Technol 44: 440.

18. Waddell WH, Beauregard PA, Evans LR (1995) Tire Technol Int 1995: 24

19. Wang MJ (1999) Rubber Chem Technol 72: 430

20. Pliskin I, Tokita N (1972) J Appl Polym Sci 16:173.

21. Dannenberg EM (1986) Bound Rubber and Carbon Black Reinforcement Rubber Chem Technol 59: 512

22. Choi S-S (2002) Properties of silica-filled styrene-butadiene rubber compounds containing acrylonitrile-butadiene rubber: The influence of the acrylonitrilebutadiene rubber type. J Appl Polym Sci 85: 385-393.

23. Goerl U, Hunsche A, Mueller A, Koban HG (1997) Investigations into the Silica/ Silane Reaction System. Rubber Chem Technol 70: 608.

24. Yatsuyanagi F, Suzuki N, Ito M, Kaidou H (2002) Polym J 34: 332.

25. Kim K-J, VanderKooi (2002) J Int Polym Proc 17:192.

26. Devaprakasam D, Hatton PV, Mobus G, Inkson BJ (2008) Effect of microstructure of nano- and micro-particle filled polymer composites on their tribo-mechanical performance. J Phys Conf Ser 126: 012057.

27. Dahl A, Gharibi A, Swietlicki E, Gudmundsson A, Bohgard M, et al. (2006) Traffic-generated emission of ultrafine particles from pavement-tire interface. Atmos Environ 40: 1314-1323.

28. Gustafsson M, Blomqvist G, Gudmundsson A, Dahl A, Swietlicki E, et al. (2008) Properties and toxicological effects of particles from the interaction between tyres, road pavement and winter traction material. Sci Total Environ 393: 226 240 .

29. Ahn S, Lee S, Kook J, Lim B (2009) Experimental antimicrobial orthodontic adhesives using nanofillers and silver nanoparticles. Dent Mater 25: 206-213.

30. Reijnders L (2008) Hazard reduction in nanotechnology. Journal of Industrial Ecology 12: 297-306. 
Citation: El-Toony MM, EI-Nemr KF (2012) Application of Acrylonitrile Butadiene Rubber for Management of Industrial Waste Silica. J Material Sci Eng 1:104. doi:10.4172/2169-0022.1000104

Page 6 of 6

31. Reijnders L (2006) Cleaner nanotechnology and hazard reduction of manufactured nanoparticles. J Clean Prod 14: 124-133.

32. Chen Z, Meng H, Xing G, Yuan H, Zhao F, et al. (2008) Age-related differences in pulmonary and cardiovascular responses to $\mathrm{SiO}_{2}$ nanoparticle inhalation: nanotoxicity has susceptible population. Environ Sci Technol 42: 8985-8992.

33. Chen M, von Mikecz A (2005) Formation of nucleoplasmic protein aggregates impairs nuclear function in response to $\mathrm{SiO}_{2}$ nanoparticles. Exp Cell Res 305: $51-62$.

34. Chang J, Chang KLB, Hwang D, Kong Z (2007) In vitro cytotoxicity of silica nanoparticles at high concentrations strongly depends on the metabolic activity type of the cell line. Environ Sci Technol 41: 2064-2068.

35. Oberdo" rster G, Stone V, Donaldson K (2007) Toxicology of nanoparticles: a historical perspective. Nanotoxicology 1: 2-25.

36. Gurr J, Wang ASS, Chen C, Jan K (2005) Ultrafine titanium dioxide particles in the absence of photoactivation can induce oxidative damage to human bronchial epithelial cells. Toxicology 213: 66-73.

37. Singh S, Shi T, Duffin R, Albrecht C, van Berlo D, et al. (2007) Endocytocis, oxidative stress and IL 8 expression in human lung epithelial cells upon treatment with fine and ultrafine $\mathrm{TiO}_{2}$ role of the specific surface area and of surface methylation of the particles. Toxicol Appl Pharmacol 222: 141-151.

38. Park E, Yi J, Chung K, Ryu D, Choi J, et al. (2008) Oxidative stress and apoptosis induced by titanium dioxide nanoparticles in cultured BEAS-2B cells. Toxicol Lett 180: 222-229.

39. Park E, Park K (2009) Oxidative stress, pro-inflammatory responses induced by silica nanoparticles in vivo and in vitro. Toxicol Lett 184: 126-133.

40. Lanone S, Boczkowski J (2006) Biomedical applications and potential health risks of nanomaterials: molecular mechanisms. Curr Mol Med 6: 651-663.

41. Lin W, Huang $Y$, Zhou X, Ma $Y$ (2006) In vitro toxicity of silica nanoparticles in human lung cancer cells. Toxicol Appl Pharmacol 217: 252-259.

42. Reeves JF, Davies SJ, Dodd NJF, Jha AN (2008) Hydroxyl radicals are associated with titanium dioxide nanoparticle-induced cytotoxicity and oxidative damage in fish cells. Mutat Res 640: 113-122.

43. Long TC, Saleh N, Tilton RD, Lowry GV, Veronesi B (2006) Titanium dioxide (P25) produces reactive oxygen species in immortalized brain microglia (BV2): implications for nanoparticle neurotoxicity. Environ Sci Technol 40: 4346-4352.

44. Jin C, Zhu B, Wang X, Lu Q (2008) Cytotoxicity of titanium dioxide nanoparticles in mouse fibroblast cells. Chem Res Toxicol 21: 1871-1877.

45. Chen XD, Wang Z, Liao ZF, Mai YL, Zhang MQ (2007) Role of anatase and rutile $\mathrm{TiO}_{2}$ nanoparticles in photooxidation of polyurethane. Polym Test 26 : 202-208.

46. Takamura M, Yamauchi T, Tsubokawa N (2008) Grafting and crosslinking reaction of carboxyl-terminated liquid rubber with silica nanoparticles and carbon black in the presence of Sc(OTf)3. J React Funct Polym 68: 1113-1118.

47. Zhao H, Sun R, Luo Y, Li J (2008) A novel method of hyperbranched poly(amide ester) modifying nano- $\mathrm{SiO}_{2}$ and study of mechanical properties of $\mathrm{PVC} /$ nano$\mathrm{SiO}_{2}$ composites. Polymer Composites 29: 1014-1019.

48. Cha H, Park OK, Kim YH, Cha HG, Kang YS (2006) Treatment of $\mathrm{TiO}_{2}$ for the suppression of photocatalytic property and dispersion stability. Int $\mathrm{J}$ Nanosci 5: 795-801.

49. Mizutani T, Arai K, Miyamoto M, Kimura Y (2006) Application of silica-containing nanocomposite emulsion to wall paint: a new environmentally safe paint of high performance. Progress in Organic Coatings 55: 276-283.

50. Mosurkal R, Samuelson LA, Smith KD, Westmoreland PR, Parmar VS, et al. (2008) Nanocomposites of $\mathrm{TiO}_{2}$ and siloxane copolymers as environmentally safe flame retardant materials. Journal of Macromolecular Science Part A 45: 924-946.

51. Thompson MR, Jeung KK (2006) Recyclability of a layered silicate-thermoplastic olefin elastomer nanocomposite. Polym Degrad Stab 91: 2396-2407.

52. Pandey JK, Reddy KR, Kumar AP, Singh RP (2005) An overview on the degradability of polymer nanocomposites. Polym Degrad Stab 898: 234-250.

53. Zeynalov EB, Allen NS, Calvet NL, Stratton J (2007) Impact of stabilizers on the thermal catalytic activity of micro- and nano-particulate titanium dioxide in oxidizing condensed mediums. J Dye Pig 75: 315-327.
54. Crystal, Garry (2008) "What are Nitrile Gloves?" wise GEEK. Conjecture Corporation.

55. Caruso F, Caruso RA, Mohwald H (1998) Nanoengineering of inorganic and hybrid hollow spheres by colloidal templating. Science 282: 1111-1114.

56. Han MG, Armes SP (2003) Preparation and characterization of polypyrrolesilica colloidal nanocomposites in water-methanol mixtures. J Colloid Interf Sci 262: 418-427.

57. Rotstein H, Tannenbaum R. Baraton MI (2003) Synthesis, functionalization and surface treatment of nanoparticles. Stevenson Ranch: American Scientific Publishers 103-26.

58. Li SD, Peng Z, Kong LX, Zhong JP (2006) Thermal degradation kinetics and morphology of natural rubber/silica nanocomposites. J Nanosci Nanotechnol 6: $541-546$.

59. Jean L, Leblanc (2002) "Rubber filler interaction and rheological properties in filled compounds", Prog Polym Sci 27: 627-687.

60. Yatsuyanagi F, Suzuki N, Ito M, Kaidou H (2002) Effects of surface chemistry of silica particles on the mechanical properties of silica filled styrene-butadiene rubber systems. Polym J 34: 332-339.

61. Bueche F (1965) Reinforcement of elastomers. NewYork: Interscience Chapter 1.

62. Suzuki N, Yatsuyanagi F, Ito M, Kaidou H (2002) Effects of surface chemistry of silica particles on secondary structure and tensile properties of silica-filled rubber systems. J Appl Polym Sci 86:1622-1629

63. Yatsuyanagi F, Suzuki N, Ito M, Kaidou H (2001) Effects of secondary structure of fillers on the mechanical properties of silica filled rubber systems. Polymer 42: 9523-9529.

64. Wagner MP (1976) Reinforcing Silicas and Silicates. Rubber Chem Technol 49: 703.

65. Zheng Peng, Ling Xue Kong, Si-Dong Li, Yin Chen, Mao Fang Huang (2007) Self-assembled natural rubber/silica nanocomposites: Its preparation and characterization, compos Sci Technol 67: 3130-3139.

66. Zhang LD, Zhang HF, Wang GZ, Mo CM, Zhang Y (1996) Dielectric behavior of nano- $\mathrm{TiO}_{2}$ bulks. Phys Stat Sol A: Appl Res 157: 483-491.

67. Zhang L, Zhong WL, Wang CL, Zhang PL, Wang YG (1998) Dielectric properties of $\mathrm{Ba} 0.7 \mathrm{Sr} 0.3 \mathrm{TiO}_{3}$ ceramics with different grain size. Phys Stat Sol A: Appl Res 168: 543-548. 